\title{
Observations on Food Remains in Faeces of Elephant, Leopard and Crabeater Seals
}

\author{
K. Green and R. Williams* \\ Antarctic Division, Channel Highway, Kingston, Tasmania 7150, Australia
}

Received 9 September 1985; accepted 18 December 1985

Summary. Faecal material of leopard, crabeater and elephant seals was collected from the vicinity of Davis station, Antarctica. Very few identifiable remains were found in elephant seal droppings. Fish remains, mainly of Pleuragramma antarcticum, were found in both leopard and crabeater seal droppings. The mysid Antarctomysis maxima was also found in crabeater seal droppings and amphipods and decapod crustaceans in leopard seal droppings.

\section{Introduction}

According to Laws (1984), the food of Antarctic seals is a "poorly known aspect of their ecology." He listed the vast area, inaccessibility of many ice areas and our general inability to observe feeding directly as factors contributing to the lack of knowledge. Øritsland (1977) summarized the small amount of information concerning food of seals in the Antarctic pack ice and found that leopard seals, Hydrurga leptonyx, take a variety of prey including krill, cephalopods, fish, birds and seals while crabeater seals, Lobodon carcinophagus, take mainly krill. Laws (1984) stated that "crabeater seals eat krill almost exclusively" and that elephant seals Mirounga leonina consume squid and fish. However, Laws (1984) stated that observations made to date indicate a regional variability in the food taken.

Most sampling to date has been conducted in the regions of the Ross and Weddell Seas leaving the $200^{\circ}$ of longitude between $40^{\circ} \mathrm{W}$ and $160^{\circ} \mathrm{E}$ basically unsampled. With regard to the management of Antarctic marine resources, the lack of data from this area is a serious omission. This study reports information, obtained in an area previously unsampled, based on the opportunistic collection of seal faeces.

\footnotetext{
* To whom reprint requests should be addressed
}

\section{Material and Methods}

Faecal material was collected in the vicinity of Davis station $\left(68^{\circ} 30^{\prime} \mathrm{S}\right.$ $78^{\circ} \mathrm{E}$ ). A total of 25 faecal samples was collected from elephant seals, 12 from moulting seals at wallows near Davis station in February 1984 and 13 from seals hauled out on nearby fast ince in June 1984. Fifteen droppings from leopard seals were collected on the fast ice edge from August to early October 1984. After the arrival of Adelie penguins, Pygoscelis adeliae, in early October, further collections were not made because droppings were generally picked over and scattered by south polar skuas, Catharacta maccormicki, before they could be collected. Two faecal samples from crabeater seals were collected in August and November 1984, respectively (Table 1 ).

All faecal samples were first washed in a sieve of $1 \mathrm{~mm}$ mesh size and the identifiable remains were sorted from the residue. Fish otoliths with little evidence of erosion were sorted into left and right and their maximum antero-posterior length was measured to the nearest $0.05 \mathrm{~mm}$ with a profile projector. The measurements were tabulated by size class and the maximum number, left or right, for each size was plotted in Fig. 1. For Pleuragramma antarcticum, an estimate of the standard length of the fish was calculated from $x=9.23+78.824 y$ where $x$ is the standard length of the fish $(\mathrm{mm})$ and $y$ the otolith length $(\mathrm{mm})$. This formula was obtained by regression analysis of the measurements of otolith length on fish standard length, obtained from fresh specimens of $P$. antarcticum.

Table 1. Frequency of occurrence $(\%)$ of prey remains in crabeater, leopard and elephant seal faeces

\begin{tabular}{|c|c|c|c|c|c|c|}
\hline & \multirow{2}{*}{$\begin{array}{l}\begin{array}{l}\text { Crab- } \\
\text { eater }\end{array} \\
n=2\end{array}$} & \multicolumn{3}{|c|}{ Leopard } & \multicolumn{2}{|c|}{ Elephant } \\
\hline & & $\begin{array}{l}\text { Aug } \\
n=9\end{array}$ & $\begin{array}{l}\text { Sept } \\
n=5\end{array}$ & $\begin{array}{l}\text { Oct } \\
n=1\end{array}$ & $\begin{array}{l}\text { Feb } \\
n=12\end{array}$ & $\begin{array}{l}\text { June } \\
n=13\end{array}$ \\
\hline Fish & 100 & 77.8 & 80 & 100 & 16.7 & 0 \\
\hline Fish eggs & 0 & 0 & 0 & 100 & 0 & 0 \\
\hline Cephalopod & 0 & 0 & 0 & 0 & 8.3 & 0 \\
\hline Mysid & 50 & 0 & 0 & 0 & 0 & 0 \\
\hline Decapod & 0 & 0 & 20 & 0 & 0 & 0 \\
\hline $\begin{array}{l}\text { Amphipod } \\
\text { Unidentified }\end{array}$ & 0 & 22.2 & 20 & 0 & 0 & 0 \\
\hline Crustacean & 0 & 11.1 & 20 & 0 & 8.3 & 23.0 \\
\hline Unidentified & 0 & 33.3 & 0 & 0 & 0 & 53.8 \\
\hline Nematode & 50 & 100 & 60 & 100 & 91.7 & 46.2 \\
\hline Stones & 50 & 0 & 0 & 0 & 0 & 0 \\
\hline Hair & 0 & 0 & $20^{*}$ & 0 & 66.7 & 0 \\
\hline
\end{tabular}


Fish vertebrae were sorted into demersal or pelagic based on the length-width ratio, the diameter of the lumen of the centrum and the thickness and degree of ribbing of the bone.

\section{Results}

Of the 25 faecal samples collected from elephant seals few had identifiable prey items. Vertebrae from both pelagic and demersal fish were identified in one sample.

Of the 15 leopard seal faeces examined, 12 contained fish remains. Pleuragramma antarcticum was the fish most commonly identified; vertebrae were found in 11 droppings and eight of these also contained a total of 420 otoliths. Vertebrae of unidentified nototheniid fish (probably Trematomus sp.) occurred in three of the droppings, one of which also contained 27 otoliths, probably from the same type of fish. Only two faecal samples contained remains of both Pleuragramma and Trematomus.

The size-frequency distribution of $P$. antarcticum from 227 otoliths collected from leopard seal droppings shows a normal distribution (Fig. 1) with the mode centred at about its size of first maturity as observed by Gorelova and Gerasimchuk (1981) in Prydz Bay. The mean calculated fish standard length was $137.6 \mathrm{~mm}$ (SD 24.3).

Examination of 20 leopard seal faeces on the sea ice from mid October to November 1984 indicated that
Adelie penguins were an important component of the diet.

Of 45 otoliths from two crabeater seal droppings, four were from $P$. antarcticum and 41 were not identifiable. Of the four $P$. antarcticum otoliths from crabeater seal faeces, three were from the top end of the size range of those collected from leopard seals (Fig. 1). One sample from a crabeater contained 75 individuals of the mysid Antarctomysis maxima, measuring approximately $20-25 \mathrm{~mm}$ in total body length.

\section{Discussion}

\section{Elephant Seals}

The absence of identifiable prey remains from elephant seal droppings was expected in the summer when elephant seals were ashore moulting. However, the prolonged presence of apparently fasting elephant seals on fast ice in June is of interest as they were not moulting.

\section{Leopard Seals}

Øritsland (1977) reported that the three most common prey of leopard seals were krill, penguins and fish. The only fishes identified were Chaenichthys sp. from a seal at Kerguelen and Paralepis atlantica from the southwestern Atlantic (Øritsland 1977). From our data, collected before the arrival of Adelie penguins, the most

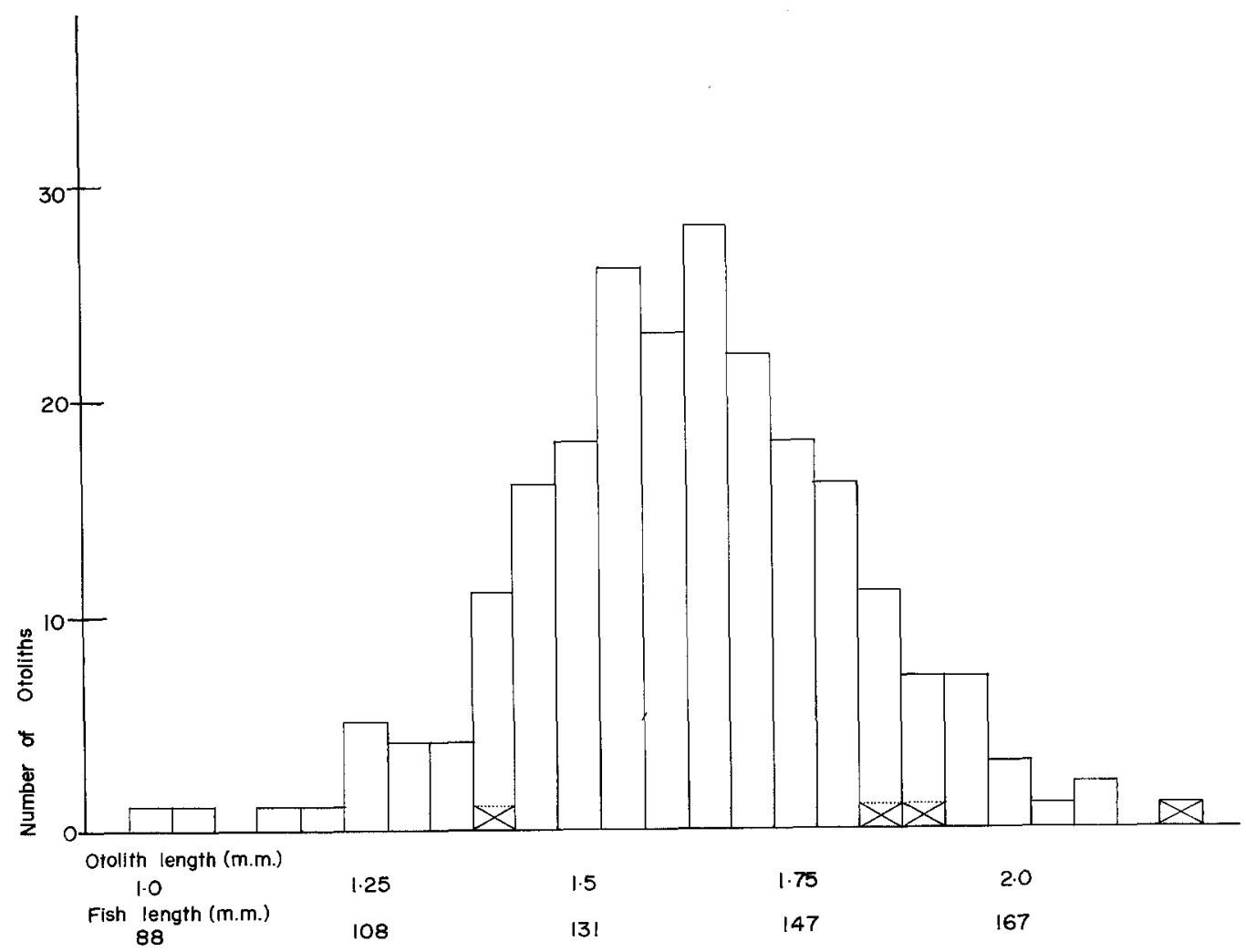

Fig. 1. Frequency of lengths of otoliths from Pleuragramma antarcticum and calculated fish standard Iength in leopard and crabeater seal faeces. $n=227$ for otoliths from leopard seals; $\mathrm{x}$ indicates single occurrence in crabeater seal faeces. Data from the two sources are superimposed, not summed 
common prey in order of descending frequency were Pleuragramma antarcticum, unidentified demersal fish, the amphipod Cheirimedon fougneri and decapod crustaceans.

Hofman et al. (1977) easily identified krill remains in seal faeces, so that differential survival of crustacean material through to the faeces should not be a problem when comparing data from faecal and stomach contents. No evidence of euphausiids was found in leopard seal faeces. The most commonly identified crustacean in leopard seal faeces was the gammarid amphipod Cheirimedon fougneri in 3 of 15 samples. Euphausiids were also absent from faecal material of the emperor penguin, Aptenodytes forsteri, sampled at Davis station during the same period and from stomach contents of Adelie penguins sampled in October and November, while $C$. fougneri occurred commonly in each. This indicates that euphausiids are not available in the study area between August and October.

It is now apparent that the food of the leopard seal varies with season and location, as postulated by Laws (1984). Our data showing a dominance of fish in the diet are from a costal site between August and October when neither krill nor Adelie penguins were available, whereas the data of Hofman et al. (1977) and Øritsland (1977) showing dominance of krill and penguin in the diet were taken from a costal site in summer and from open pack ice in winter respectively, when both krill and penguins were available.

Also, the sampling site at Davis $\left(68^{\circ} 35^{\prime} \mathrm{S}\right)$ is considerably further south than Øritsland's (1977) area $\left(58^{\circ}\right.$ to $62^{\circ} \mathrm{S}$ ) or that of Hofman et al. (1977) at $64^{\circ} 46^{\prime} \mathrm{S}$. Pleuragramma antarcticum is a circumpolar high latitude continental shelf species abundant in Prydz Bay (Williams et al. 1983) which would explain its predominance in the fish component of the diet at Davis but not in other areas so far studied.

\section{Crabeater Seals}

The mysid A. maxima is a characteristic member of the Antarctic neritic zooplankton community and has been recorded in the food of a number of Antarctic fish (Ward 1984) but seldom before in seals.

Of the 100 food samples from Crabeater seals reported by Øritsland (1977), the majority contained Euphausia superba. Of the 100 samples, 27 were collected by Wilson (1907) and 65 by Øritsland (1977) from two broad areas off the Antarctic continental shelf. The few food samples collected over the continental shelf, however, contained remains of prey other than $E$. superba. Marr (1962) reported that contents of stomachs collected by Lindsey (1938) and Perkins (1945) contained E. crystallorophias while Perkins (1945) also reported octopus occurring occasionally. Schultz (1945) and this study reported the pelagic fish $P$. antarcticum. This study also reports the mysid $A$. maxima. The few samples collected in continental shelf waters therefore indicate that crabeater seals are opportunistic feeders.

Croxall and Prince (1979) stated that "the Crabeater Seal feeds virtually exclusively on krill" and suggested that "it is clearly of substantial importance to be able to detect changes in reproductive capacity, especially those which may result from changes in abundance of prey stock". In view of the evidence that crabeater seals are more opportunistic than previously thought, a more thorough examination of their diet over a wider area and also on a seasonal basis is necessary to determine what food sources they actually prey upon.

Acknowledgements. Thanks to Messrs. D. Reid for his help in the field and D. Turner for measurement of otoliths. Mr. H. R. Burton and Dr. E. Guiler commented on the manuscript.

\section{References}

Croxall JP, Prince PA (1979) Antarctic seabird and seal monitoring studies. Polar Rec 19:573-595

Gorelova TA, Gerasimchuk VV (1981) Data on nutrition and daily consumption of juvenile Pleuragramma antarcticum Boulenger. In: Parin NV (ed) Fishes of the open ocean. Acad Sci USSR, Moscow, pp $103-109$

Hofman RJ, Reichle RA, Siniff DB, Muller-Schwarze D (1977) The leopard seal (Hydrurga leptonyx) at Palmer Station, Antarctica. In: Llano GA (ed) Adaptations within Antarctic ecosystems. Smithsonian Institution, Washington, pp 769-782

Laws RM (1984) Seals. In: Laws RM (ed) Antarctic ecology, Vol 2. Academic Press, London, pp 621-715

Lindsey AA (1938) Notes on the Crab-eater seal. J Mammal $19: 456-461$

Marr J (1962) The natural history and geography of the Antarctic Krill (Euphausia superba Dana). Discovery Rep 32:33 - 464

Øritsland T (1977) Food consumption of seals in the Antarctic pack ice. In: Llano GA (ed) Adaptations within Antarctic ecosystems. Smithsonian Institution, Washington, pp $749-768$

Perkins JE (1945) Biology at Little America III, the west base of the United States Antarctic service expedition, 1939-1941. Proc Am Philos Soc 89:270-284

Schultz LP (1945) Fishes of the United States Antarctic service expedition, 1939-1941. Proc Am Philos 89:298

Ward P (1984) Aspects of the biology of Antarctomysis maxima (Crustacea:Mysidacea). Polar Biol 3:85 - 92

Williams R, Kirkwood J, O'Sullivan D (1983) FIBEX cruise zooplankton data ANARE Res, Note 7, $163 \mathrm{pp}$

Wilson EA (1907) Mammalia (seals and whales). In: National Antarctic expedition, 1901-1904. Natural History, Vol 2. (Zool) British Museum (Natural History), Lơndon, pp 1-66 